\title{
Biological features of metabolism in rhesus monkeys as a result of the inclusion of fish meal in the structure of feeding rations
}

\author{
Nikolay Gaponov ${ }^{{ }^{*}}$, and German Yagovenko ${ }^{l}$ \\ ${ }^{1}$ All-Russian Research institute of lupine - branch of the NSC "All-Russian Research Institute of \\ fodder named after V.R. Williams", 241524, Berezovaya str., 2, Michurinsky village, Bryansk \\ district, Bryansk region, Russia
}

\begin{abstract}
The article presents a study of the effect of fish meal, in the amount of $18 \%$ in the structure of the diet, on the organism of primates. Fishmeal is known to be rich in energy and protein. One kilogram of it contains up to $700 \mathrm{~g}$ of pure protein and up to $15 \mathrm{MJ}$ of exchangeable energy. It should be noted that fish meal is easily digested and well absorbed by the body of animals. Among other things, it contains a lot of calcium, fat, vitamins of group B, phosphorus and other elements. But the use of fish meal in the rations of primates, in an amount above $10 \%$, has not been sufficiently studied. Therefore, the purpose of our research was to study the effect of fish meal on hematological, biochemical blood parameters, to determine the variability of rations of rhesus monkeys, and based on the data obtained to determine the prospects for its further use in feeding primates. For this purpose, developed technological methods of preparation of feed with fish meal. The chemical composition of the obtained feeds has been determined. The nutritional value of the feed obtained was studied by the main indicators of chemical composition. The effect of fishmeal rations on blood and biochemical blood parameters and nutrient digestibility of fishmeal rations on rhesus monkeys was studied. And also calculated the economic efficiency of the use of fish meal in the structure of ration. On the basis of experimental data, it was established that the introduction of fish meal into the diet provides an improvement in the process of assimilation of feed, which has a beneficial effect on hematological and biochemical blood parameters in experimental primates. And provides a reduction in the cost of full granular feed.
\end{abstract}

\section{Introduction}

Quality feeding rations underpin the profitability of keeping primates and all animal species, and fish meal is one of the most important components of a quality diet. Fish forage meal produced at modern fat-meal enterprises has valuable forage properties. It was found that fish meal protein is digested by animals much better than vegetable feed protein.

\footnotetext{
*Corresponding author: nv.1000@bk.ru
} 
Experience shows that fish meal added to animal feed increases the efficiency of other foods that are poor in protein and fat; the use of fish meal in mixed feed contributes to acceleration of growth of animals, increase of their weight, improvement of the general condition $[15,11,14]$. As a result of biochemical studies in fish fodder products the socalled protein factor (AP) was found; it is essential for animal assimilation of vegetable protein, vitamin $\mathrm{B} 12$ and other water-soluble B vitamins, including riboflavin and pantothenic acid, which has a strong impact on animal growth and development. In this regard, fish forage meal is not only a source of full-fledged animal protein, but also a catalyst in biochemical processes. [1,2] Thus, experiments of the Leningrad Zootechnical Institute established that animals which digested $31.8 \%$ of nitrogen from vegetable feed, started to digest up to $36.3 \%$ of nitrogen after adding $5 \%$ of cod meal to feed, i.e. digestibility of plant proteins increased by $12.5 \%[12,11]$. Therefore, introduction of fish meal in the feed diet contributes to healthy development of animals. Fish meal has a unique composition. First of all, we are talking about a surprisingly wide complex of natural substances and minerals that are contained in fish meal: phosphorus (it is rich in almost all seafood), as well as calcium, a whole set of amino acids, iodine, selenium, as well as vitamins A, D and group B. Each of these elements has its own useful properties. Thanks to which digestive processes are improved, and immunity is strengthened. Fish meal occupies one of the first places among feed products in terms of digestible protein content. Thus, 1 $\mathrm{kg}$ of fish meal contains at least $535 \mathrm{~g}$ of digestible protein. Therefore, animals receiving fish meal are less susceptible to diseases, and due to the optimal ratio of amino acids in the composition of fish meal, young animals develop faster, maintain immunity and have reduced stress. Fish meal is considered to be a valuable health product against goiter diseases as it includes iodine in the form of organic compounds. For example, cod fat contains 4.5 to $15.2 \mathrm{mg}$ per $1 \mathrm{~kg}$ of fat. $[5,9,13,12]$

The chemical nature of extractive substances of fish meal is not sufficiently studied yet. However, the favorable effect of high varieties of fish meal on appetite of animals was established. The animals receiving fish meal well digest a significant amount of feed and grow fast. Thanks to its components it contributes to the development of vital systems of the body: the immune system is activated, the digestibility of nutrients increases, young animals develop better $[16,18]$. Quality fish meal digestibility reaches $90 \%$. In addition, the introduction of fish meal has a positive effect on feed conversion, and the better conversion, the more cost-effective is the production. This is confirmed by numerous experiments in livestock farming. Therefore, this property is widely used in the manufacture of combined feeds, which have a great popularity in our country.

The aim of our research was to study the effect of fish meal on the body of rhesus monkeys and to determine the prospects for its further use in primates feeding.

To achieve these goals, it was necessary to solve a number of tasks:

-develop technological methods of preparation of feed with fish meal

-determine the chemical composition of the received feed in the laboratory

-assess the nutritional status of the received feed according to the basic parameters of

the chemical composition and qualitative characteristics and to draw up feeding rations

-study the effect of rations with fish meal on hematological and biochemical indices of primate blood

-study digestibility of nutrients of the diet with fish meal on rhesus monkeys

-calculate the economic efficiency of the use of fish meal in the structure of the rations

-carry out mathematical processing of the received data

\section{Methods of research}


In order to achieve the set goals and achieve the objectives, scientific research was carried out on male rhesus monkeys. For that there were 2 groups formed aged from 7 to 15 years 5 heads in each group, by the method of pairs of analogues by type, origin, age and physiological condition, in the conditions of vivarium on the basis of the FSBI Research Institute of medical primatology. In accordance with generally accepted research methods developed by the All-Russian Research Institute of Animal Husbandry and other organizations $[9,10,5,17]$.

All animal studies were conducted in accordance with the requirements of the Committee on Bioethics and the Federal Law of the Russian Federation on the protection of animals from cruel treatment (Article 4 of the Law of the Russian Federation on the protection of animals from cruel treatment) of December 01, 1999).

The obtained results were processed statistically and expressed in the form of arithmetic averages and their standard errors. The statistical significance of differences was determined by means of one-factor dispersion analysis with subsequent a posteriori comparisons using the Dunnett method and the $\mathrm{t}$-criterion of Student. The differences were considered valid at the level of statistical significance $\mathrm{p}<0.05$.

Experiment diagram is presented in Table 1

Table 1. Experiment diagram

\begin{tabular}{|c|c|l|}
\hline \multirow{2}{*}{ Groups } & \multirow{2}{*}{$\begin{array}{c}\text { Quanti ty } \\
\text { of animals }\end{array}$} & \multicolumn{1}{|c|}{ Feeding conditions } \\
\cline { 3 - 3 } & 5 & Macaca mulatta aged 7 - 15 years \\
\hline $\begin{array}{c}\text { I } \\
\text { Control }\end{array}$ & 5 & CF- (18\% Fish meal $)$ \\
\hline $\begin{array}{c}\text { II } \\
\text { Experimental }\end{array}$ & 5 & \\
\hline
\end{tabular}

Studies of fish meal and other feed components were carried out in the laboratory, on the basis of the obtained laboratory data and background information, according to the norms, the diet of feeding primates was compiled. The obtained complete feed was pelletized on the equipment of MUENCH Edelstahl GmbH (Germany). The obtained complete granular feed was fed to rhesus monkeys (Macaca mulatta).

Primates in the control group during the trial period got the full feed produced at the production site of FSBI "Research Institute MP". In had $21.4 \%$ of energy nutrient accounted for wheat. The share of soybean cake in the structure of feed accounted for $17.42 \%$. Sunflower cake $(10 \%)$ provides a diet for $13.83 \%$. A significant part of the energy of the diet is skim milk powder and it is $14.39 \%$. The diet of the control group was balanced by the introduction of sunflower oil, which amounted to $0.8 \%$. The remaining $32.16 \%$ of energy accounted for gluten corn $11.24 \%$, corn $13.35 \%$, egg powder $3.3 \%$ and sugar $4.27 \%$

The second experimental group in the structure of the diet contained $18 \%$ of fish meal. Due to the inclusion ( $60-65 \%$ ) of fish meal the content of skim milk powder was decreased by $100 \%$, sunflower meal by $10.00 \%$, egg powder by $70 \%$, corn gluten by $2 \%$ and so on. The ration is balanced according to raw protein. There is a slight shortage of raw fiber, but it is within the acceptable norm. For other nutrients deviations are within the norm. $[4,6$, 7].

Health condition and change of homeostasis of primate organisms, as a result of inclusion of the studied feed was monitored according to the analysis results of hematological and biochemical indicators of blood. To this end, blood was taken before the primates were put on the experiment and after the completion of the experimental feeding. 


\section{Research results}

Hemopoietic organs react sensitively to various physiological and, in particular, patho-

\begin{tabular}{|c|c|c|c|c|c|c|c|c|c|c|}
\hline \multirow[t]{2}{*}{ Type } & $\begin{array}{c}\text { Leukocytes } \\
\text { (WBC) }\end{array}$ & \begin{tabular}{|c|} 
Erythrocytes \\
(RBC)
\end{tabular} & $\begin{array}{c}\text { Hemoglobin } \\
\text { (HGB) }\end{array}$ & $\begin{array}{l}\text { Hematocrit } \\
\text { (HCT) }\end{array}$ & \begin{tabular}{|c|} 
Average \\
erythrocyte \\
volume \\
$(\mathrm{MCV})$
\end{tabular} & $\begin{array}{c}\text { Average } \mathrm{Hb} \\
\text { content in } \\
\text { red blood } \\
\text { cells }(\mathrm{MCH})\end{array}$ & $\begin{array}{c}\text { Anizocytosis } \\
\text { of } \\
\text { erythrocytes } \\
\text { (RDW) }\end{array}$ & $\begin{array}{l}\text { Platelets } \\
\text { (PLT) }\end{array}$ & $\begin{array}{l}\text { Average } \\
\text { platelet } \\
\text { volume } \\
\text { (MPV) }\end{array}$ & ESR \\
\hline & $5.5-13$ & $5-6.2$ & $110-145$ & $0.26-0.45$ & $52-97$ & 18- 33 & $11-16$ & $200-400$ & $6-10$ & $0.5-5$ \\
\hline \multicolumn{11}{|c|}{ At the beginning of the experiment } \\
\hline Control & $\begin{array}{c}9.82 \\
\pm 1.65 \\
\end{array}$ & $\begin{array}{c}6.30 \pm \\
0.05 \\
\end{array}$ & $\begin{array}{c}143.40 \\
\pm 1.40 \\
\end{array}$ & $\begin{array}{c}0.43 \\
\pm 0.01 \\
\end{array}$ & $\begin{array}{l}67.80 \\
\pm 0.42 \\
\end{array}$ & $\begin{array}{l}22.76 \\
\pm 0.29 \\
\end{array}$ & $\begin{array}{l}12.98 \\
\pm 0.20 \\
\end{array}$ & $\begin{array}{l}308.40 \\
\pm 18.15 \\
\end{array}$ & $\begin{array}{c}9.74 \\
\pm 0.19 \\
\end{array}$ & $\begin{array}{c}0.89 \\
\pm 0.10 \\
\end{array}$ \\
\hline $\begin{array}{l}2- \\
\text { experiment }\end{array}$ & $\begin{array}{c}10.01 \pm \\
1.21 \\
\end{array}$ & $\begin{array}{c}6.11 \pm \\
1.14 \\
\end{array}$ & $\begin{array}{c}144.31 \pm \\
1.62 \\
\end{array}$ & $\begin{array}{c}0.43 \pm \\
0.01 \\
\end{array}$ & $\begin{array}{c}68.00 \pm \\
0.65 \\
\end{array}$ & $\begin{array}{c}22.80 \pm \\
0.15 \\
\end{array}$ & $\begin{array}{c}13.01 \pm \\
0.30 \\
\end{array}$ & $\begin{array}{c}298.11 \pm \\
19.21 \\
\end{array}$ & $\begin{array}{c}9.81 \pm \\
0.21 \\
\end{array}$ & $\begin{array}{c}1.10 \pm \\
0.23 \\
\end{array}$ \\
\hline \multicolumn{11}{|c|}{ At the end of the experiment } \\
\hline Control & $\begin{array}{l}10.82 \\
\pm 1.99 \\
\end{array}$ & $\begin{array}{c}6.43 \\
\pm 0.17 \\
\end{array}$ & $\begin{array}{c}145.00 \\
\pm 0.5 \\
\end{array}$ & $\begin{array}{c}0.43 \\
\pm 0.00 \\
\end{array}$ & $\begin{array}{r}68.20 \\
\pm 0.42 \\
\end{array}$ & $\begin{array}{l}22.84 \\
\pm 0.30 \\
\end{array}$ & $\begin{array}{l}13.22 \\
\pm 0.29 \\
\end{array}$ & $\begin{array}{r}316.00 \\
\pm 25.62 \\
\end{array}$ & $\begin{array}{r}9.94 \\
\pm 0.33 \\
\end{array}$ & $\begin{array}{c}0.91 \\
\pm 0.11 \\
\end{array}$ \\
\hline $\begin{array}{l}2- \\
\text { experiment }\end{array}$ & $\begin{array}{l}10.73 \\
\pm 0.69\end{array}$ & $\begin{array}{c}6.39 \\
\pm 0.20 *\end{array}$ & $\begin{array}{c}145.20 \pm \\
3.19\end{array}$ & $\begin{array}{c}0.44 \\
\pm 0.01\end{array}$ & $\begin{array}{l}68.00 \\
\pm 0.61\end{array}$ & $\begin{array}{l}23.06 \\
\pm 0.26\end{array}$ & $\begin{array}{l}13.26 \\
\pm 0.37\end{array}$ & $\begin{array}{l}287.60 \\
\pm 23.13\end{array}$ & $\begin{array}{c}10.02 \\
\pm 23.24\end{array}$ & $\begin{array}{c}1.30 \\
\pm 0.63\end{array}$ \\
\hline
\end{tabular}

logical effects on the body by changing the pattern of blood. Therefore, blood testing has a great diagnostic value

Table 2. Hematological parameters of blood $(\mathrm{X} \pm \mathrm{Sx})$

$$
\mathrm{p}<0.05^{*}
$$

Erythrocytes (RBC), their main function in the body is transportation of oxygen and removal of carbon dioxide. At the beginning of the experiment, the level of erythrocytes in the experimental group was within the limits of the reference values. There was a slight increase in the control group. And at the end of the experiment the level (RBC), both in the control group and in the experimental group, slightly exceeded the reference values, but in the experimental one the level of red blood cells was closer to normal.

The breathing function of erythrocytes is inextricably linked to the properties of the hemoglobin protein contained therein. Therefore, an important indicator is the level of hemoglobin, which depends on the content of protein, iron, copper and cobalt in the diet, as well as on the functioning of the liver and hematopoietic organs. In our experiment, the results of the studies indicate that the level of hemoglobin in the blood before being tested is within the limits of the physiological norm. At the end of the experiment as a result of the use of fish meal, there was a slight increase in hemoglobin (HGB) in the experimental group compared to the control group by $0.14 \%$. This may be due to the abovementioned physiological increase in the level of erythrocyte concentration in blood.

Leukocytes are responsible for the function of immunity. Their concentration in the blood directly affects the overall functioning of the immune system. This means that the level of leukocytes in blood is able to indicate the degree of protection of the body as a whole. In our experiment, the level of white blood cells at the beginning and at the end of the experiment was within normal limits. Yet at the end of the experiment there is a slight increase in the control group compared to the experimental one, which indicates that fish meal has no negative effect on the immune system of the body. This phenomenon can have 
a natural physiological character. The increase in white blood cells is noted with the increase in ambient temperature. This type of increase is reversible, in this case leukocytosis is able to return independently to the normal range of values.

Platelets have properties of aggregation (gluing). They contain biologically active substances that determine their participation in the mechanisms of blood coagulation and fibrinolysis, in providing angiotriphic function. At the time of the experiment, the number of platelets in rhesus monkeys was within the limits of the referent values from 200 to 400 billion/l. In both groups, both at the beginning and at the end of the experiment, platelets were within the reference values.

The rate of erythrocyte sedimentation (ERS) depends on the size, volume of erythrocyte, their quantity, the concentration of hemoglobin in erythrocyte, viscosity and other factors. Due to the optimal picture presented by the abovementioned indicators (Table 2 ), the ERS is within the range of $0.5-5.0 \mathrm{~mm} / \mathrm{h}$. Fluctuation of hematological parameters within physiological norms, that the use of fish meal in the amount of $18 \%$ in the structure of the dietdoes not change the stability of hematopoiesis and permanence in composition and total number of peripheral blood, but has a positive effect on resistance and hemopoiesis.

Along with morphological parameters, biochemical values of blood have a certain value in internal non-communicable diseases, intoxications, but in a greater degree reflect the level of feeding and metabolic processes. In this regard, biochemical indicators with correct understanding of physiological changes become a solid basis for decision-making on the development of scientifically grounded norms of feeding table 3.

Table 3. Biochemical parameters of blood $(\mathrm{X} \pm \mathrm{Sx})$

\begin{tabular}{|l|c|c|c|c|c|}
\hline \multicolumn{1}{|c|}{ Groups } & $\begin{array}{c}\text { Glucose } \\
(\mathrm{mmol} / \mathrm{L})\end{array}$ & $\begin{array}{c}\text { Bilirubin } \\
(\mathrm{mcmol} / \mathrm{L})\end{array}$ & $\begin{array}{c}\text { Phosphorus } \\
(\mathrm{mmol} / \mathrm{L})\end{array}$ & $\begin{array}{c}\text { Calcium } \\
(\mathrm{mmol} / \mathrm{L})\end{array}$ & $\begin{array}{c}\text { Protein } \\
(\mathrm{g} / \mathrm{l})\end{array}$ \\
\hline \multicolumn{7}{|c|}{ At the beginning of the experiment } & \\
\hline Control & $4.43 \pm 0.44$ & $6.99 \pm 2.74$ & $1.17 \pm 0.19$ & $2.56 \pm 0.06$ & $89.31 \pm 8.40$ \\
\hline 2-experiment & $3.97 \pm 0.34$ & $7.01 \pm 1.81$ & $1.09 \pm 0.13$ & $2.13 \pm 0.14$ & $82.98 \pm 4.11$ \\
\hline \multicolumn{7}{|c|}{ At the end of the experiment } \\
\hline Control & $3.32 \pm 0.38$ & $6.98 \pm 1.47$ & $0.61 \pm 0.13$ & $2.01 \pm 0.16$ & $80.12 \pm 1.66$ \\
\hline 2-experiment & $3.27 \pm 0.38^{*}$ & $7.17 \pm 1.47$ & $0.65 \pm 0.11$ & $2.04 \pm 0.13$ & $82.73 \pm 1.34$ \\
\hline
\end{tabular}

Blood glucose levels were determined to monitor the state of carbohydrate metabolism. At the beginning of the experiment, the glucose level was within the physiological norm. At the beginning of the experiment there is a slight increase in the control group. But at the end of the experiment, after application of fish meal in feeding, the level of glucose in the experimental group approached the indicators of the control group. 
Bilirubin is a bile pigment that appears from hemoglobin as a result of the decay of erythrocyte liver cells. In the experimental group, the level of bilirubin at the end of the experiment slightly increases within the norm by $0.19 \mathrm{mmol} / \mathrm{l}$.

The level of phosphorus in the blood of the control group at the beginning of the experiment was slightly higher than the control group but was within the reference values. By the end of the experiment, the values in the experimental and control group were aligned.

The level of calcium in the serum depends on the content of calcium, phosphorus and vitamin $\mathrm{D}$ in the diet, the state of the hormonal system and the gastrointestinal tract. In the experiment, the level of calcium at the beginning and end of the experiment was within normal limits. But in the experimental group the calcium level is slightly higher by 0.03 $\mathrm{mmol} / \mathrm{l}$.

Total protein in blood serum was studied to diagnose metabolic disorders and feeding primates. The analysis of protein metabolism showed that in the 2-experimental group deviations from the control in the direction of increase by $2.61 \mathrm{~g} / 1$ were observed. This indicates the positive effect of fish meal on the body of primates.

Thus, on the basis of the abovementioned, it can be concluded that the quality of the diet feeding of male macaca mulatta with the inclusion of fish meal affected the morphological and biochemical blood indicators. Changes in blood indicators indicate good health of primates and their full-value nutrition.

In order to determine digestibility and use of nutrients of rations, a physiological experiment was carried out on 10 heads of primates of the macaca mulatta species. Daily accounting of feed eaten by animals and conducted analysis of their chemical composition allowed to establish the amount of nutrients consumed per day. And the accounting of stool and its chemical composition allowed to determine the amount of digested nutrients and to establish the digestibility coefficient table 4 .

Table 4. Nutrient digestibility, $\%(\mathrm{X} \pm \mathrm{Sx})$

\begin{tabular}{|c|c|c|c|c|c|c|c|}
\hline Indicators & Raw protein & Raw fat & Raw fiber & Raw ash & $\begin{array}{c}\text { Raw } \\
\text { NFES }\end{array}$ & Calcium & Phosphorus \\
\hline Control & $\begin{array}{c}27.34 \pm \\
1.04\end{array}$ & $\begin{array}{c}20.09 \pm \\
0.98\end{array}$ & $\begin{array}{c}16.88 \pm \\
1.01\end{array}$ & $\begin{array}{c}49.58 \pm \\
0.88\end{array}$ & $\begin{array}{c}54.05 \pm \\
1.12\end{array}$ & $\begin{array}{c}18.37 \pm \\
1.94\end{array}$ & $\begin{array}{c}21.79 \pm \\
2.01\end{array}$ \\
\hline 2-experiment & $\begin{array}{l}29.00 \pm \\
1.14 * *\end{array}$ & $\begin{array}{c}42.01 \pm \\
1.85\end{array}$ & $\begin{array}{c}52.13 \pm \\
1.26\end{array}$ & $\begin{array}{c}53.63 \pm \\
1.03\end{array}$ & $\begin{array}{c}42.31 \pm \\
1.27\end{array}$ & $\begin{array}{c}94.14 \pm \\
1.18^{*}\end{array}$ & $\begin{array}{c}90.00 \pm \\
1.84\end{array}$ \\
\hline
\end{tabular}

Analysis of the data of Table 4 indicates that the best digestibility results of the most of normalized organic substances were observed in the primates of the experimental group. Thus, in the experimental group, where fish meal was used in the structure of the diet, protein absorption in relation to control was higher by $1.66 \%$ with reliability $\mathrm{p}<0.01$. Raw fat from an experimental diet feeding was better absorbed by $21.92 \%$. Raw ash in the experimental group was better digested by $4.05 \%$. For other indicators and macroelements, there is a significant difference in the direction of increase in the experimental group in calcium by $75.77 \%(\mathrm{p}<0.05)$ and phosphorus $69 \%$.

Obtained digestibility data indicates that the inclusion of fish meal in the diet structure of primates had a positive effect on the absorption of basic nutrients, especially its inorganic parts. 
Since economic indicators of efficiency of feeding primates are among the main indicators of the profitability regulation system of their contents, we have calculated the indicators of cost production of experimental full feed with fish flour in comparison with the control.

So in the structure of the diet 1-control group, the main expensive component is skim milk powder, its share accounts for $-14,29 \%$, the price was 24 rubles 20 kopeykas (24.20). The high cost was formed as a consequence of the high purchase cost and its significant content in the diet feeding. The next expensive component is soybean cake, it accounts for $17.42 \%$ or 9.66 rubles. The highest purchase cost was in egg powder and as a result, although its content is insignificant, in the structure of the ration it had $3.3 \%$ and price amounted to 6.98 rubles. The cost of remaining components of the diet is at an acceptable level. This is due to their initial low cost or low percentage content in the diet structure. The price of $1 \mathrm{~kg}$ of full feed for the control group amounted to 70,96 rubles.

During the preparation of feeding rations of primates of the 2-experimental group, the structure of the diet underwent a significant change. In particular, fish meal has replaced soybean meal by $7 \%$, sunflower meal by $10 \%$, egg powder by $50 \%$, skim milk powder by $100 \%$. In total, in the structure of the feeding diet fish meal $(60-65 \%)$ in terms of energy nutrition amounted to $18 \%$ or 6.84 rubles., the cost of $1 \mathrm{~kg}$ was 48.38 rubles. Thus, as a result of fish meal inclusion in the structure of full feed, it was managed to reduce the cost of $1 \mathrm{~kg}$ of feed compared to the 1 -control group by 22.58 rubles.

The cost of the exchange energy of rations also depends on the cost of feed and the nutritional value of feed. In the 1-control group, the cost of $1 \mathrm{MJ}$ was 5.32 rubles. The lowest cost of exchange energy was in the experimental group, and it amounted to 3.63 rubles per $1 \mathrm{MJ}$. A similar pattern is observed on protein. Lowest cost per $1 \mathrm{~g}$ of protein was in the experimental group, and it amounted to 0.14 rubles, and in the control group the cost of protein was 0.26 rubles .

\section{Conclusion}

Analyzing the obtained data of the experiment it is possible to conclude that the inclusion of fish meal in the structure of full feed for primates, which previously wasn't used in the structure of rations, can provide enrichment of rations with nutrients, improve the resistance of the body, ensure better absorption of nutrients and reduce the cost of feed without losing its quality.

\section{References}

1. V. I. Vorobyov, E. V. Nizhnikova, O. T. Lempert, N. P. Nefedova. News of KSTU, № 38 (2015)

2. P. I. Viktorov, V.K. Menkin, B43 Methods and organization of zootechnical experiments, 112 (M.: Agropromizdat, 1991)

3. N.V. Gaponov, Bulletin of KrasSAU, 7 (148), 96-102, (2019)

4. N.V .Gaponov, Y.P. Chuguev, I.I. Chugueva, Veterinary medicine, 1, 43-47, (2020)

5. N.V. Gaponov, S.V. Svistunov, Journal of Scientific Papers, Krasnodar Scientific Center for Animal Engineering and veterinary medicine, 8(1), 188-193, (2019)

6. N.V. Gaponov, Yu.P. Chuguev, I.I. Chugueva, Actual problems of medicine, 6, 16-22, (2019)

7. N.V. Gaponov, G.L. Yagovenko, Feed production, 2, 43-46, (2020) 
8. V.N. Degtyarev, Hydromechanical processes of treatment of hydrobionts, 171 (Petropavlovsk-Kamchatsky: KamchatSTU, 2008)

9. A. I. Ovsyannikov, Fundamentals of Experimental Business in Animal Husbandry, 304 (M. : Kolos, 1967)

10. A.P. Kalashnikov et [al.] Norms and rations of feeding farm animals: reference manual. 3rd ed. revised and enlarged, 456 (M., 2003)

11. V.M. Poznyakovsky, O.A. Ryazanova, T.K. Kalenik, V.M. Datsun, Examination of fish, fish products and non-fish objects of water fishing. Quality and safety, 331 (Novosibirsk: Editorial of the Siberian University, 2005)

12. E.I. Lebedev, Complex use of raw materials in the food industry: monograph, (Moscow: Food industry, 1992)

13. Filinere marine: les nouvelles technologies, Process, 1068, 17-19 (1992)

14. Y. Masumura, Journal gerontology, 386-390, 26(3), (1971)

15. R.D. Miles, F.A. Chapman, The benefits of fish Meal in Aquaculture diets (University of Florida, USA, 31.07.2006). URL: http:// www.thefishsite.com/articles/200/the-benefitsof-fish-meal-in-aquaculture-diets

16. G.K. Grimble, D.B.A. Silk, Milk proteins: nutritional, functional and technological aspects, 270-281 (Stein-kopft Vergal, Darmstagt, Germany, 1989)

17. N.V. Gaponov, S.V. Svistunov, N.N. Bondarenko, I.A. Romanenko, Bulletin the National academy of sciences of the Republic of Kazakhstan, 2(384), 22 - 28, (2020)

18. K. Yatsunami, T. Takenaka, Fish. Sci., 62(62), 790-795, (1996) 